DOI: https://doi.org/10.34069/AI/2021.46.10.12 How to Cite:

Goloborodko, I., Kostikova, I., Bozhko, Y., Holoborodko, K., \& Malenko, O. (2021). Bob Dylan's Art Concern: Semantic Acoustics of Poetic Texture. Amazonia Investiga, 10(46), 128-137. https://doi.org/10.34069/AI/2021.46.10.12

\title{
Bob Dylan's Art Concern: Semantic Acoustics of Poetic Texture
}

\section{Арт-концерн Боба Ділана: семантична акустика поетичних текстів}

Received: September 13, 2021

\begin{abstract}
The manuscript focuses on the complex of semantic aspects associated with the development and textual evolution of Bob Dylan, the Nobel Prize winner for literature in 2016. The article deals with the semantic acoustics of some famous Bob Dylan's poetic texts that have become the musical and literary classics of the twentieth century. The splicing edges of Bob Dylan's poetic texts are distinguished; they have intellectual and sensual, visual and visionary, imaginative and emotional, metaphorical and direct, semantic and acoustic principles. The relationship between the structure and the semantic phonics of some texts is studied. The paper emphasizes on the urgency, acute sociability and ontology, universal philosophy of his poetic texts. There is a neomodern poetic experimentation in some Bob Dylan's texts, he seems to overcome time limits and, in fact, to combine different historical times, cultural epochs, mental values. The article summarizes that Bob Dylan's art concern has influenced polyphonically and creatively to the various artistic spheres of the second half of the twentieth
\end{abstract}

Accepted: October 28, 2021

\author{
Written by: \\ Iaroslav Goloborodko ${ }^{40}$ \\ https://orcid.org/0000-0002-4563-7684 \\ Ilona Kostikova ${ }^{41}$ \\ https://orcid.org/0000-0001-5894-4846 \\ Yuliia Bozhko ${ }^{42}$ \\ https://orcid.org/0000-0002-7235-0670 \\ Kostiantyn Holoborodko ${ }^{43}$ \\ https://orcid.org/0000-0001-6004-4003 \\ Olena Malenko ${ }^{44}$ \\ https://orcid.org/0000-0003-4753-0036
}

\begin{abstract}
Анотація
У статті докладно аналізується комплекс семантичних проблем, пов'язаних 3 розвитком, становленням i текстовою еволюцією визначного американського поета i музиканта Боба Ділана, - лауреата Нобелівської премії з літератури 2016 року. У статті детально розглядається семантична акустика окремих поетичних текстів Боба Ділана, що стали музичною і літературною класикою XX століття. Виокремлюються грані зрощення в поетичних текстах Боба Ділана інтелектуального й почуттєвого, візуального і візіоністського, образного й емоційного, метафоричного й автологічного, семантичного й акустичного начал. Досліджується взаємозв'язок структури й семантичної фоніки окремих його текстів. Акцентується на актуальності, гострій соціумності й онтологічності, універсальній філософічності низки його поетичних текстів. Відзначається неомодерна поетична експериментальність окремих текстів Боба Ділана, у яких він мовби долає часові межі й фактично сполучує різні історичні часи,
\end{abstract}

\footnotetext{
${ }^{40}$ Doctor of Science in Philology, Full Professor, Department of Ukrainian Philology, Horlivka Institute of Foreign Languages in Donbass State Pedagogical University, Ukraine.

${ }^{41}$ Head of the Department of Theory and Practice of the English Language, Doctor of Science in Education, Ph.D. in Philology, Ph.D. in Education, Full Professor, H. S. Skovoroda Kharkiv National Pedagogical University, Ukraine.

${ }^{42}$ Ph.D. in Philology, Associate Professor, Department of Theory and Practice of the English Language, H.S. Skovoroda Kharkiv National Pedagogical University, Ukraine.

${ }^{43}$ Dean of H.F. Kvitka-Osnovianenko Ukrainian Language and Literature Faculty, Department of the Ukrainian Language, Doctor of Science in Philology, Full Professor, H.S. Skovoroda Kharkiv National Pedagogical University, Ukraine.

${ }^{44}$ Head of the Department of Ukrainian Studies and Linguistics, Doctor of Science in Philology, Full Professor, H.S. Skovoroda Kharkiv National Pedagogical University, Ukraine.
} 


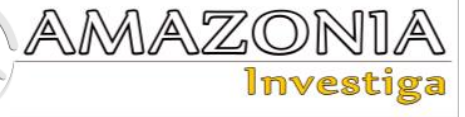

century, becoming one of the drivers of world trends in literature, music culture, and cinematography. Methodology. In accordance with the paper purpose the following methods are used: the method of scientific literature analysis, the comparative method, the method of conceptual analysis, the method of sampling texts. An important role also has the descriptive method, which includes generalization, systematization and interpretation of the obtained data. The research also relies on methods of description, comparison, systematization.

Keywords: Bob Dylan, creative faces, Nobel Prize winner, poetic texts.

\section{Introduction}

On May 24, 2021, the famous American musician and Nobel Prize winner for literature Bob Dylan was 80 years old. For six decades of his artistic career he accumulated several dozen creative faces. Universal Bob Dylan's creative faces are most productively interpreted through the prism of cluster optics, cluster analytical technology. This needs to appeal within the limits of one study to his poetic texts and prose, as well as his musical and cinematic facts of his art image. It constructs and models the architecture of purely inherent connections between the various niches of his art practice. It brings us closer to understanding Bob Dylan's true depth of his nature projected the dramatic complexity and enigmatic nature of his art staff. Finally, the article purpose is to discover Bob Dylan's art concern in general as for semantic acoustics of his poetic texture.

\section{Theoretical Framework or Literature Review}

Bob Dylan is such a multi-faceted and multidimensional personality (Vernezze, \& Porter, 2005) in a creative sense that he can be represented as a multi-instrumentalist, taking into account the results of his creative activities in the field of music (Shelton, 2011), literature, cinema, and painting (Weberman, 2016), (Weberman, 2019). And in all these artistic niches one worked in different roles (Holubnycha et al., 2020) and in different genres (Kryvoruchko et al., 2021), trends (Kostikova et al., 2020), directions (Demchenko et al., 2021).

Bob Dylan's artistic phenomenon is quite problematic to divide into separate creative культурні епохи, ментальні цінності. У підсумках статті узагальнюється, що артконцерн Боба Ділана поліфонічно й креативно вплинув на різні мистецькі сфери другої половини XX століття, ставши одним i3 драйверів світових тенденцій у літературі, музичній культурі, кінематографі. Методологія. Відповідно до мети роботи використовуються такі методи: метод аналізу наукової літератури, порівняльний метод, метод концептуального аналізу, метод вибірки текстів. Важливу роль відіграє також описовий метод, який включає узагальнення, систематизацію та інтерпретацію отриманих даних. Дослідження також спирається на методи опису, порівняння, систематизації.

Ключові слова: Боб Ділан, творчі обличчя, лауреат Нобелівської премії, поетичні тексти.

images, as is the case when his creativity is interpreted as a musician (Markhorst, 2019a), who created in poetry (Heylin, 2010), (Heylin, 2011), literature. Sometimes he is interpreted as a poet realizing himself in the genres of folk, country, rock music (Mangel, 2018), rock-androll (Markhorst, 2019b). No doubt, there is a deep genetic connection between poetry and music (Bell, 2011).

We agree that "the poetry of our time in general, and lyrics in particular, for the centuries has forgotten its musical origin, and the connection of lyrics and music in the mental trends of the 21 st century does not seem so natural" (Chernokova, 2017, p. 489). However, the connection was "natural, it is worth mentioning only the folk roots of ancient Greek melika or the separation a tragedy and epic from choral culture" (Chernokova, 2017, p. 489).

Music as an art niche for its amplification may require implicitly a poetic text, organized verbally forms. Poetry as a creative impulse sounds often as it provokes associations about different music genres or provides explicitly a soundtrack format, arrangement, musical design (Markhorst, 2019c). When such an objective opportunity arises music and poetry make sense not to separate, not to divide, but on the contrary to consider them in mutual contact and mutual magnetism (Glazer, 2019).

But researchers studied mostly the different parts of Bob Dylan's creativity: the biography separately, the songs separately, the music 
separately, so, art versatility and artistic multiinstrumentalism are not analyzed yet.

\section{Results and Discussion}

\section{Dynamic stratagem and art self-identification}

When Robert Zimmerman started his creative activity, he did not immediately become Bob Dylan. Choosing his name carefully enough, he wanted it to be concise, significant and pleasant-sounding. One of his temporary earlystage aliases was Elston Gunn, but he had a gut feeling that it was not fully satisfactory to him. He also considered taking the artistic alias Robert Allen or Robert Allin. He was already about to choose Robert Allyn as the stage name, but according to his autobiography called "Chronicles", "unexpectedly, I'd seen some poems by Dylan Thomas" (Dylan, 2004, p. 78).

Taking into consideration the fact that he was always called "Robert or Bobby" (Dylan, 2004, p. 78) in his family as he himself pointed out, he decided to combine the two names in the pseudonym: the borrowed name and the shortened own one. So, getting to know the works by the Anglo-Welsh writer, who lived to just 39 and wrote poems, stories, plays, novels, helped the musician to solve his name problem, which actually conveyed his understanding of the significance of the unusually expressed word.

Bob Dylan started his music career with cover versions and for several years he acted as a singer-interpreter, as a follower folk singer, and it was quite satisfying for him. Bob Dylan's first songs include "Talkin' New York" and "Song to Woody". Both texts relay upon the idea of the poet's starting positions and help him feeling the dynamics, tension and evolution of the intellectually artistic route he had to overcome. “Talkin' New York” (album 'Bob Dylan', 1962) is an unpretentious story of the same unpretentious narrator who presents himself, his own person under a deliberately understated, simplistic perspective. This narrator does not claim to be anyone in a life, since he perceived a life as a physically wandering, mostly geographical process. To live for him means to be in a next regular another place. The characternarrator lives without any claims to the environment. If he has any claims they are expressed in a way of not seeking the place in the sun. Because he does not need at all his sustainable, lively and at least prosperous place. A life for him is simple, transparent, obvious; there are no ambiguities, vague places in it.
'Song to Woody' (album 'Bob Dylan', 1962) is a half tone or even a whole tone more complex. In the album the figurative reality comprehension wakes up. Or perhaps it would be more accurate to say: the album declares a figuratively metaphorical diagnosis of the surrounding time space. And the narrator himself in the more intense registers and more saturated overtones begins to perceive his relationship with life. Life heartache penetrates into artist's nature. In addition to the narrator, the text has another character Woody Guthrie: "Hey, hey, Woody Guthrie, I wrote you a song", "Hey, Woody Guthrie, but I know that you know".

Bob Dylan easily got used to living in the environment of American and English music and song culture, to tunes, lyrics, feelings and emotions inspired by these compositions, peculiarities of singing and technique. It was important for him to get the lay of the land, step and rely on it to fundamentally determine the principles of his work as a musician who writes and performs his songs.

\section{Social mainstream and conscious archipelagos of freedom}

Bob Dylan made a move quite worthy of a person who would later gain the status of the Nobel Prize winner, he decided to deeply understand his present, time being, having let the electric current of the past through himself. To be more exact, the electric current of the American past. He was determined to feel it, see and touch the highvoltage frequencies of the national past. He wanted to be struck, feel through his skin and understand the present time to make up the poetic-musical-semantic priorities of his own creative activity.

Intellectualism of "Chronicles" is one of the most fascinating intrigues of this prose text, in which Bob Dylan is extremely subtle and astute in diagnosing the American time-space. And then and there, in the reading room, perhaps, something the most essential and the most profound happened, Dylan felt an invisible, but no less deep connection, the contact of a split, naked in his extreme images of a century past with the relatively stable present in which he was, and he realized for himself that since then the essence of human nature had not changed at all, and that the real, super dramatic processes had been hidden so-called imaginary human wellbeing of the present.

In other words, if Dylan's life is to be directed by his imaginative instrument "the light", then he 


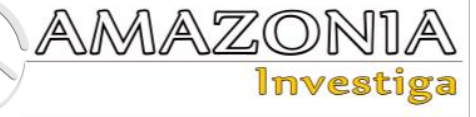

"could see the full complexity of human nature" (Dylan, 2004, p. 86). The single word man is now no less difficult and / or very difficult than, say, a hundred years or so ago, that a true, real life for Dylan is one that carries with him disharmonyloss-bursts-suffering-pain. And then, while working at the New York Public Library, Bob Dylan actually decided to formulate a conceptual platform for his work as a poet, composer, and musician: "The godawful truth of that would be the all-encompassing template behind everything that I would write" (Dylan, 2004, p. 86). This will become the general motto of most of his compositions, in which the key place will surely belong to the leitmotif dominant concept of "the godawful truth".

The dominant concept conveys a subjectively multifaceted, individually varied vision of the world with optics of an indivisibly rigid and uncompromising view-invasion peculiar to military night vision devices. This dominant concept began to emerge in texts of the first half of the 1960s, such as "Blowin' in the Wind", "Masters of War", "A Hard Rain's a-Gonna Fall”, “Talkin' World War III Blues" containing a sketch-outline of Bob Dylan's poetics and can be interpreted as a kind of poetic plein air on which the artist absorbs all the circulation of moods, feelings, thoughts, impulses literally dissolved in the social environment.

The text of "Blowin 'in the Wind" (album "The Freewheelin' Bob Dylan”, 1963) shows a through constructive technique: an appeal to a person who lives in one of the narrator's time and may have a mental-thinking acoustic in common with him (the narrator). The narrator expresses the emotional and mental anxiety and appeals to those who think and look into the eternal as well as actual signs of the outside world, who are expecting difficult, even painful questions and are ready to accept, absorb them in their minds. In the text "Blowin "in the Wind," the fragrant lyrical beginning touches / borders / intersects and becomes emphatically social.

"Masters of War" (album "The Freewheelin' Bob Dylan", 1963) is from the first word, more precisely, the cartridge to the last is a non-fiction text, in which the verses of the pamphlet are loud in every stanza. "The narrator positions himself as an exceptionally sociable person; he is all on the trail of topical issues, he reflects on the problem and the phenomenon of the newest anabasis, proclaimed and supported by those whom he labels with the frame "masters of war". But this trail leads the narrator to a non-military, counter-military strategy for human relations, as he realizes that the world's anabasis will turn into a total catabasis.

The narrator's axiological imperative is life for life, not for destruction and death, he is ready to go to the end, not to go down his non-military path and to go along to the physical end of those who are classified as "masters of war" the development of the variant, motive, collision of death is able to satisfy him. The narrator puts on the garments of the seer and the prophet, to whom the morning twilight of truth is revealed. The same hidden from many, and possibly from all the truth as the freeway to life and the highway from death.

"A Hard Rain's a-Gonna Fall" (album "The Freewheelin' Bob Dylan”, 1963) is a very visual and visionary text. It looks like it is painted on rough sheets of paper, or maybe on a large canvas, or, say, on long, concrete walls that run along not too crowded track. This text does not have the foreground and the details that shade, use with effect, strengthen it. "A Hard Rain's aGonna Fall" is a poetic drawing in which every component of the construct is important, equilibrium, and at the same time its semantic and visual expressiveness "does not press" on those components that are in front of it or right behind it. The realias of this text are organically charged with a somewhat affective or ecstatic convention, in which the symbolism is mixed with metaphor and a good old surrealism.

“Talkin' World War III Blues" (album "The Freewheelin' Bob Dylan”, 1963) is a text with a plot that features two characters who don't mind talking because they both like this process itself, especially the one who is communicatively "active". These two are the narrator and his doctor, psychotherapist or psychiatrist. For the text, it is not probably important which doctor it really is, although it would be more complete if it was a psychiatrist, since he is imperceptibly similar to his verbally energetic patient. Yes, it really would be better if it was a psychiatrist, and the explanation is obvious: the narrator in details describes his dream to the doctor, and this dream is an attractive or phantasmagoric one, both of them are sincerely empathetic to this dream, plunging into its fabulous passages in which the breath of tragicomedy is guessed.

The main part of “Talkin' World War III Blues" consists of unreal visions, narrator's crazy dream, which tells the reader how he unexpectedly got into a seemingly dreamy situation, "into World War Three". The prolific narrator describes the events as if he belongs to a 
very egalitarian society, but his taste for witty quotes (for example, with reference to Abraham Lincoln) says that in the sense of mind he is a smart guy just trying on a mask of a gawk.

The narrator is undoubtedly a cool storyteller and presents his own dreams with genuine immediacy and audacious irony, which, however, does not so much emphasize his inner "craziness" but explains his hyper-healthy and super calm self-esteem. With the sense of curiosity of the adventurous situations that occurred to him in his sleep, he was also fine. In general, all of this story, modeled on "Talkin' World War III Blues", is presented without obvious sentention (which, incidentally, is inherent in "Masters of War"), but not without acute social connotation veiled by the naivelycasual nature of the narration.

In the first half of the 1960s, Bob Dylan wrote a series of poetic texts that in the American society of that period were interpreted as "protest songs". The musician himself did not accept such a terminological definition of his compositions that came under this qualification. He used his own terminological matrix and called them "topical songs" neutralizing that conflicting resource which potentially implied the termframe "protest songs". The conceptual frame of "topical songs" according to Bob Dylan's view, most accurately conveyed the idea which he expressed as a poet, composer and performer in his works.

He realized that texts with meaningful topical content were a very good chance for the performer and a poet to come up with his own interpretative version of the circumstances and tendencies that disturb and galvanize society. And for all the reason, such texts also focus attention on the personality of the musician, give him opportunities to value and consciously influence the society. Bob Dylan reflected on this aspect: "I had been singing a lot of topical songs, anyway. Songs about real events were always topical. You could usually find some kind of point of view in it, though, and take it for what it was worth, and the writer doesn't have to be accurate, could tell you anything and you are going to believe it" (Dylan, 2004, p. 82).

Topically-based songs open up for a poet and musician actually unlimited space of vital facts, genuine subject matter, associative logic or fantasy. At the same time, they either do not exclude or imply any concepts, a generalized view of the selected or covered life facts. It is not a coincidence that Dylan, looking for what he called "song material" (Dylan, 2004, p. 87), often looked through contemporary newspapers hoping to find in them specific information that would push him to a new idea.

At the same time, the "song" format (as opposed to the "protest song" format) does not oblige a songwriter to become a participant - in the broad sense - of a political or any social movement. The "topical song" code sticker guarantees the musician the right to aesthetically and (more importantly) artistic freedom - both consciously intellectual and purely behavioral, legitimizing not only the artist's autonomy but also his independence from the pressure or even dictatorship of social movements.

Apparently, that's what Bob Dylan meant when he argued, not without polemical fervor, while reflecting on his early poetic and musical works: "Topical songs weren't protest songs. The term "protest singer" didn't exist any more than the term "singer - songwriter". You were a performer or you weren't, that was about it-a folksinger or not one. "Songs of dissent" was a term people used but even that was rare. I tried to explain later that I didn't think I was a protest writer, that there'd been a screwup. I didn't think I was protesting anything..." (Dylan, 2004, p. 82-83).

Undoubtedly, Dylan with his peculiarly subtle sense of social, even macro-social situation, was well aware that his lyrics and compositions such as "Blowin' in the Wind", "Masters of War", "A Hard Rain's a-Gonna Fall" inspiringly correlated with the activities of expansive-minded Americans, the tumultuous rebellious youth and intellectual groups of the 1960s.

Assuredly, he was also aware that this overlay of his lyrics to mainstream social sentiments just brings, lobbies, provides his songs with guaranteed success. However, Dylan as an artist did not intend to focus only on current issues, no matter how acutely social they were, and at the same time solely on folk music, he did not want to move or be forced to move in a single poetic and musical direction having no alternative. He sought not to be an artist-for-society, but an artist-for-his-freedom. He strived to develop in the poetic and musical directions according to his intuition, his nature, first and foremost present himself, his conscious archipelago of freedom. "I was not a spokesman for anything or anybody and that I was only a musician", Bob Dylan insisted (Dylan, 2004, p. 119). 


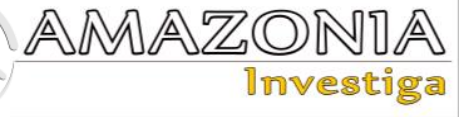

Speaking first of all about his own artistic priorities, about his development of different genres of music, Dylan reflected: "As far as I knew, I didn't belong to anybody then or now" (Dylan, 2004, p. 115). However, this selfdetermination formula is transposed into his whole artistic figure.

\section{Different continental poetry as an art concept and an art platform}

All his life, Bob Dylan has sought to be an artist who tells what his nature wants and how his nature wants it. His non-belonging to anyone (in a purely axiological and musical sense, too) is not a verbal-manifesting maxima, thrown into for solely external use, but a pivotal immanent formula that he guided and professed in his own actions. It (this formula) is caused by a couple of inseparable, like loyal friends, internal drivers, a heightened sense of mental and behavioral freedom and a super-dynamic nature of the artist, for whom it was unthinkable and impossible to lock up within the same music genre, whether these were folk, rock, or single text issues. "No one single idea keeps you contented for too long", as if he was a systematic philosopher, Bob Dylan aphoristically sums up (Dylan, 2004, p. 85).

Modern human nature is a category that is doomed (even against its own free will) to chronically forced transformation or internal self-transformation. Bob Dylan felt that it was very desirable to feel these changes, not to resist them, but on the contrary - to follow them, even if they brought with them complexities and extreme stress of development, he felt it subtly, shrewdly and sensitively, and therefore with the knowledge of the case stated: "Human dynamics plays too big a part, and getting what you want isn't always the most important thing in life anyway" (Dylan, 2004, p. 218).

In his deep and thinking nature, two basic qualities have emerged: intellectual selfsufficiency and analytical criticality. And it is not easy to determine which of them is more significant, decisive. In art, as in life, Dylan is willing to play by the rules he sets himself, and to lead a party by someone else's rules is not his game. This was revealed in all his poetic and musical dynamics, which appeared after the series of "topical songs" and presented in the dimension of the mid and second half of the 1960 s - by aesthetically diverse continental texts such as "Maggie's Farm", "Mr. Tambourine Man", "Like A Rolling Stone", "Desolation Row", "Visions of Johanna", "All Along the
Watchtower", "The Ballad of Frankie Lee and Judas Priest".

"Maggie's Farm" (album "Bringing It All Back Home", 1965) is a rhythmically structured text. It is revealed by the distich that in a slightly transformed form with refrain goes through the whole text and performs the function of the deck on which there is another important cargo of this text-ship. Generally "Maggie's Farm" has the image of a small well-decorated vessel on which people are hanging about and which, with all this, is frantically tossing on the waves, which throw it, or ready to absorb, then hurriedly slow it down.

Between the layers of the refrain, distich there are stanzas that develop the main dynamic motive, the stay of the narrator on unforgettable for him "Maggie's Farm", which, of course, either deeply engraved or etched into his feelings. The basic intonation of the poetic text is a perfectly sarcastic drive that permeates into every smallest cell of the narrator, who seems to be about to explode from those ironically critical sensations that overwhelm him.

However, despite all the narrator's troubles and negative emotions, the pulse of his own dignity is beating, with which (dignity) he is not going to part in his life. In addition to Maggie herself, other members of this undoubtedly colorful family are introduced in the text, all of these unique Brother, $\mathrm{Pa}$, and $\mathrm{Ma}$, taken in their entirety as a whole, are a complete exoticphysiological clinics. Maxim in the text sounds seemingly obvious, but this is no less profound and rigid in its indisputable sentiment, the irresistibly attractive essence of which is that the human society, without even noticing it, constantly plays the tyrannical role of Procruste, trying to fit every person in their perfect patterns: "But everybody wants you / To be just like them!”.

The text "Mr. Tambourine Man" (album "Bringing It All Back Home", 1965) is a semantic multi-passage, a kind of multifaceted metaphorical combination whose interpretative plots can evolve in completely different directions and depend primarily on the subjective values of the interpreter. The scale of the metaphor strikes with its simultaneous watercolor and engraving, which evokes a sense of resinous airiness and delicate roughness of the narration.

Metaphor permeates in the text far and wide, vertically, horizontally, in volume, metaphor is 
represented here as mental excess, as a figurative turbulence, as a universal consistency of thinking, as a kind of "black hole" that absorbs and keeps every detail or every reality abstract. The character of the narrator, whether he feels or he really is in the time where there is no sign of a specific time.

The narrator is an imaginary character, if not imaginary bizarre, as the enigmatic $\mathrm{Mr}$. Tambourine Man, whom he constantly addresses. The figure of Mr. Tambourine Man clearly appeals to the narrator, with a clear psychological affinity between them, perhaps even a mutual mental disposition, which is extremely important for the narrator, who has a vital contact with the person. Mr. Tambourine Man is the kind of musician who helps the storyteller travel in time and fantasy, in space and imagination, with which he acquires a level of imaginative freedom that enables him, the narrator, to feel and experience the maximum bliss of inner vision. Maybe "Mr. Tambourine Man" is a disguised legend about the freedomloving resources of the human spirit that overcomes any laws of physical, historical, and intellectual gravity.

"Like A Rolling Stone" (album "Highway 61 Revisited", 1965) is a text about the transformations of destiny, perhaps even the devilish transformations, when you can have more than anything, and be left with more than nothing. Life may well be perceived as a very valuable and beautiful toy, say, like a colorful Barbie doll, manifested in all its beauty, in all its outward splendor. And one day, this trendy Barbie toy, doll, fun not only fails, but breaks down brutally, and breaks down so that it is no longer repairable. The text of "Like A Rolling Stone" tells the story of such a life-as-a-toy story when it is no longer real to go up but only down when shiny and deceptively attractive dresses, decorations, outfits, accessories on life-as-a-toy are not left any longer.

Life presented and packaged in a bright wrapper, in its unfolded form, actually proves to be unadorned with no beauty, and it goes without saying that it embraces any of its features and sides, except for attractive ones. "Like A Rolling Stone" is a concrete and seemingly down-toearth story with no specific meanings which have deadly cold and love to any turns of such an obscure thing as life. It is just Dylan's text that recalls the "godawful" sense of barefaced ruthlessness of the impulses that reality sends to a man.
The text "Desolation Row" (album "Highway 61 Revisited", 1965) can be represented as a compressed neo-modern poem, charismatic feature of which is stunning trails or image zigzags. And the narrator acts as a stuntman, performing exciting and even risky tricks.

At the same time he manages to modestly stay in the background that suits a real stuntman, especially during filming, even if it is verbal. Or the narrator is associated with a wandering medieval saga man that tastes pirate rum and travels mostly between Europe and America, and in his spare time watches Hollywood classics, reads Notre-Dame de Paris, Milorad Pavic, Cendrill / Cendrill Aschenputtel by Charles Perrault or the Brüder Grimm and tries to find "inconsistencies" in the special and general theory of relativity.

Desolation Row is a trans-logical narration in which another charismatic feature is the plot of wholly adventurous turns of a mentally figurative route, turns that cannot be rationally calculated, intuitively predicted or even irrationally figured out.

These twists, deliciously flavored with strong spices of detective stories, feature figures of different real and fictional stories, and their poetic and temporal cultural space, at least, intrigues: Cinderella, Romeo, Cain and Abel, Ophelia, Einstein, Robin Hood, Neptune, Casanova, Ezine Pound and Tseliot. Everything is connected with everything, everyone is with everything, all is totally connected with everything. There is nothing unlikely, nonintersectional in real-time and in real-life space, and Ezra Pound becomes a living contemporary of Romeo or vice versa, and Casanova does not become inaccessible to the chronotope that featured Cain and Abel.

Time is steadily moving backward, as if catching up with the past that had escaped forward. Space is supposedly split or, more precisely, defragmented, including in order to appear in an even more structured or organized whole. Such is magical realism, or magical surrealism, or naturalistic-phantom realism in poetic format.

Incidentally, a character under the specific Phantom code can also be found on the Desolation Row character show, this spontaneously aligned text with a major as the plot logistics driver. In general, after the super translogical narration, "Desolation Row" it makes clear what is behind it. That's the way the galactic metalogical novel Tarantula, written by 


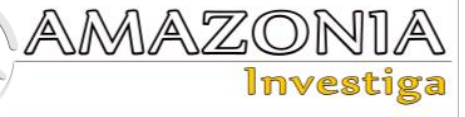

Bob Dylan during 1965-1966, appeared. But the exclusive routes of Tarantula metalogic are, as they say, a completely different story.

"Visions of Johanna" (album "Blonde on Blonde", 1966) is a delicate filigree and gourmet knit "fabric" in which every sub-fragment seems to play - whether in the dimension of a single detail, outlined with self-evident relief, or in the dimension of a stand-alone image that fits perfectly into the overall composition. Most likely, it is a kind of macrame, perhaps even macrame cavandoli, only given in verbal format. Macrame is so private, so subtle, so intra-tonal, it is what puts you in an elegiac mood, a barely perceptible heart intonation. "Visions of Johanna" is a text with a gently fluid female duration.

And it is not because here nostalgically comes Louise, or ubiquitous Mona Lisa, or "these visions of Johanna", or the sacred Madonna, it is clear that the text is written by a man who has the gift of enjoying the enigmatic perfumes of feminine nature. The masculine gaze gives this text a heavenly aroma of earthly femininity. "He" is always nearby, always close, though, as if from the distance of a hidden eye, somewhere, but "she" always receives gentle bouquets of his attention. It's not so easy between "he" and "she", though not so hopelessly complicated.

Each of them has its own line, these lines are not so parallel, but they usually intersect when they do not have to do it at all. In the Visions of Johanna macrame, you can see either drawings touching the lyrical history of the yin, yang with its various psychological patterns, or a knot of whimsical slides that flushes the subjective, observational vision of the narrator, or the ordinary life mandala, into which everyone lives on his or her own wave, and in the end, develops as it would in a normal private existence: colorful, brutal, elegant and somewhat unexpected at times.

The text "All Along the Watchtower" (album "John Wesley Harding", 1967) is marked by the eloquent conciseness of the form and the provocative nonchalance of its semantics. It is based on dialogue, a very short dialogue featuring two characters Joker and Thief. These two, charmingly symbolic two, express two entities - different, seemingly opposed, but not conflictedly sharpened.

Joker stares intently and ponders what is happening around him, he is deeply disturbed by what he sees and watches, people live deeply without thinking, no one wants to live meaningful life, everything is not as it should be, human life is an all-encompassing disharmony, perhaps even a holiday, a kind of carnival of professionally organized disharmony, in which almost everyone is heard, but in the end, almost everyone loses.

Thief, on the contrary, does not take life and everything else too seriously, one has to live without straining and complicating everything, everyone came by chance to this world, and so will leave this place peacefully, nothing is impossible to change, it is better to take everything as it is, and not to please ourselves that each of us is capable of at least influencing something, in this world everything has long been defined, and it is, indeed, better for each of us to acknowledge it and not to have any hopes.

The text "All Along the Watchtower" is imbued with a neat ontological background that is amplified by its not loud but very meaningful final chords: time passes and life goes on, and the figurative dialogue between the symbolically emblematic Joker and Thief remains incomplete. And who is right here, and whether someone here may be right, and whether there is anyone right in a cardinal collision of worldviews - it all hangs in the air. And the philosophical phonics of "All Along the Watchtower" is undoubtedly enhanced by the semantic-semiotic capacity and formal condensation of this text.

"The Ballad of Frankie Lee and Judas Priest" (album "John Wesley Harding", 1967) has a consequent plot and, to say the least, it is a thoroughly poetic text that does not in any way cancel out its entire allegory. The focus of the narration is the dynamic conflict that has unfolded in the relationships of those who considered themselves friends and may have almost been them until the time $\mathrm{X}$ came.

The part of this time $\mathrm{X}$ in the text is entrusted with the card game, the game, where the bet is not only money, but a fatal fall into dependence on another person, when one of the players and friends loses any power over himself and his life. Frankie Lee is portrayed as the friend-victim and rather allusive character, Judas Priest as the victim-hunter and even more allusive. In the ballad, it becomes immediately clear that a collision of allegorical-everyday dimension is hidden in the seemingly down-to-earth situation. Frankie Lee and Judas Priest are friends, antipodes, antipolars, and in their own way antinomies, that, of course, do not exist separately by themselves. 
One distinguishes the fatalistically doomed beginning, the other has fatally devilish, Mephistophelesian beginning. One continually goes both to his own expected death and to his inexorable death. The other also constantly replenishes his own bank accounts with deaths. This whole story is an ever-present format of this kind of business partnership: Frankie Lee is a reliable contributor to his death, and Judas Priest is a successful banker, of course, of strangers' deaths. Others who appear situationally in this story are intermediaries between these two participants in a business event or even a transaction where events are unfolded on the classical "give-and-take" principle, as if human life is at stake.

And this is also quite realistic / symbolic: in business affairs, whatever they may be, they cannot go without dealers of different kinds. The semantic sound of "The Ballad of Frankie Lee and Judas Priest" is characterized by overtones of natural, mystical, infernal sound, the transitions of which are quite flexible and unobtrusive. The text mixes up the monophonic and everyday polyphonic meanings of life, which, like barriers on the sports track, are more or less evenly spaced throughout the narration distance.

Such a structure brings the "Ballad of Frankie Lee and Judas Priest" closer to the parable format, more precisely, the synthesis-parable or modern-parable, in which the subjugated life and contour metaphysical one are fused, in which the confessional and allegorical, domestic and symbolic, eventual and general are intertwined, in which you can always "dig" so deep that you can even lose the feeling of the earth beneath your feet and see all the magic of the abyss, which with a romantic danger opens before the mental sight.

Dylan singles out Sinclair Lewis, who, as he emphasizes, was "from Sokenter, Minnesota" and "wrote" Elmer Henry "and was a master of absolute realism, invented it" and what the musician especially emphasizes, is the fact he "won the Nobel Prize in Literature, was the first American to succeed". The mention of Sinclair Lewis in the epic "Chronicles" now, after the decision of the Nobel Committee in 2016, looks like an invitation to the analytical parallel between these two Nobel Prize winners, outlined at least in general terms. Sinclair Lewis was born and spent his childhood in the province, in one of Minnesota's small cities (Sinclair, 2021), and later he thought how he had come to the conclusion that it is possible, without violating the rules of decency write truthfully about the people of Sook Sentre, Minnesota (Sinclair, 2021).

There were periods in his life when he "worked ... as an editor in New York" (Shkliar, \& Shpytal, 2006, p. 95), nicknamed "Tom Graham" and published his first books, Hike and the Aeroplane, 1912, and “Our Mr Wrenn”, appealed to various genre formats in literature. Significant is the fact that Sinclair Lewis was characterized by a critical, often barbed-critical perception of the surrounding American reality, embodied in his novels and especially concentrated in the Nobel speech 'The American Fear of Literature' (Sinclair, 2021).

\section{Conclusions}

To conclude it is necessary to say that Bob Dylan is a mysterious organics of two opposing modes, it is rarely combined in one art persona: spectacular sensibility and plot intelligence. His literary and artistic practice retransmits polyphonically and structurally sensory art culture. At the same time his practice is a powerful generator of intellectual art productivity.

Bob Dylan's poetic lyrics are impressively colorful by nature. His music and melodies are run through expressive cinematography. His voice, timbre, vocals gravitate towards the prose analyticity. Bob Dylan's creative figure and mega personality is associated with his art concern. His art concern will manifest itself for a long time in different portals of the creative spirit, keeping the self-confident society at a distance from itself and taking care about the development of the universal infinity of different shelves in the figurative consciousness.

\section{Bibliographic references}

Bell, I. (2012). Once Upon a Time: The Lives of Bob Dylan. Mainstream Publishing. ISBN 978-1-78057-573-5.

Chernokova, Y. (2017). The Metaphor of Circus as a Trope in the Lyrics by B. Yeats and Bob Dylan. Modern Literary Studies. Literary Dimensions of Spectacular Forms of Culture, 14 , 484-495. http://nbuv.gov.ua/UJRN/Sls_2017_14_46 [in Ukrainian]

Demchenko, V., Kostikova, I., Bozhko, Y., Holoborodko, K., \& Malenko, O. (2021). The concept "Information" as a factor in Bernard Werber's style. Amazonia Investiga, 10(40), 265-274. https://doi.org/10.34069/AI/2021.40.04.26 


\section{AMAZOND㲏}

Dylan, B. (2004). Chronicles. Vol. 1. New York City: Simon and Schuster.

Glazer, R. A. L. (2019). Bob Dylan's existential dreidel. Canadian Jewish News. https://www.cjnews.com/culture/entertainme nt/bob-dylans-existential-dreidel

Heylin, C. (2010). Still On the Road: The Songs of Bob Dylan, Volume Two: 1974-2008. Constable. ISBN 1849015988; ISBN 9781849015981

Heylin, C. (2011). Bob Dylan: Behind the Shades: 20th Anniversary Edition. Faber and Faber. ISBN 978-0-571-27240-2.

Holubnycha, L., Kostikova, I., Besarab, T., Moshtagh, Y., Lushchyk, Y., \& Dolgusheva, O. (2020). Semantic and Structural Aspects of Donald Trump's Neologisms. Postmodern Openings, 11(2Sup1), 43-59. https://doi.org/10.18662/po/11.2Sup1/178

Kostikova, I., Bozhko, Y., Razumenko, T., \& Goloborodko, E. (2020). The Translation Peculiarities of the Ancient Ukrainian Monument «On the Campaign of Igor» by American Researchers Jack Haney and Eric Dahl. Amazonia Investiga, 9(28), 545-551. http://dx.doi.org/10.34069/AI/2020.28.04.59

Kryvoruchko, S., Kostikova, I., Gulich, O., Harmash, L., \& Rudnieva, I. (2021). Genre transformation in Simone de Beauvoir's work "Force of Circumstance". Amazonia Investiga, $\quad$ 10(38), 245-251. https://doi.org/10.34069/AI/2021.38.02.24

Mangel, A. (2018). "Through Me Tell the Story": A New Historical Analysis of Bob Dylan's Rock Poetry (A Thesis for Master of Arts in English Literature and Language). St. Mary's University https://commons.stmarytx.edu/cgi/viewconte nt.cgi? article $=1017 \&$ context $=$ dissertations
Markhorst, J. (2019a). As I Went Out One Morning I Bumped into WH Auden and Borrowed His Notebook. Untold Dylan. https://bob-dylan.org.uk/archives/12112

Markhorst, J. (2019b). Black Crow Blues, a Touch of Van Gogh (and More Crows). Untold Dylan. https://bobdylan.org.uk/archives/11752.

Markhorst, J. (2019c). Knockin' On Heaven's Door: Change, Change Again. Untold Dylan. https://bob-dylan.org.uk/archives/11626.

Shelton, R. (2011). No Direction Home: Life and Music of Bob Dylan. Omnibus Press. ISBN: 1617130125 ISBN: 978-1617130120.

Shkliar, L., \& Shpytal, A. (2006). Under the Nobel Sign. Nobel Prize Winners in Literature 1901 - 2006. Kyiv: Hramota. https://lib.kherson.ua/publ.pid-znakomnobelya-966-349-040-3; ISBN 966-349040-3 [in Ukrainian].

Sinclair, L. (2021, October 23). The American Fear of Literature. Nobel Lecture. The Nobel Prize,

https://www.nobelprize.org/prizes/literature/ 1930/lewis/lecture/

Vernezze, P. \& Porter, C. (2005). Bob Dylan and Philosophy: It's Alright Ma (I'm Only Thinking). Chicago: Open Court Publishing.

Weberman, A. (2019). Encyclopedia Dylanologica. Vol. 2. The State of the Art in Dylanology.

https://ru.scribd.com/document/442012883/ Encyclopedia-Dylanologica-Volume-2.

Weberman, A. (2016). Encyclopedia Dylanologica. Vol. 1. Center for Advanced Dylanological Study. https://www.academia.edu/41715726/THE_ ENCYCLOPEDIA_DYLANOLOGICA_V OLUME_ONE. 